УДК 332.14

Панкова Л.І., к.е.н., доцент кафедри менеджменту та бізнес-адміністрування Черкаський державний технологічний університет

Потапенко Т.П., здобувач кафедри менеджменту та бізнес-адміністрування Черкаський державний технологічний університет

\title{
ФОРМУВАННЯ КЛАСТЕРНИХ МОДЕЛЕЙ НАЦІОНАЛЬНИХ ЕКОНОМІК НА ЗАСАДАХ СТИМУЛЮВАННЯ РЕГІОНАЛЬНОГО РОЗВИТКУ
}

У статті розглянуто фундаментальні напрями теорії регіональної економіки та регіонального менеджменту, що стали підгрунтям розвитку кластреної теорії. Надано авторське визначення кластерної моделі розвитку національної економіки, обгрунтовано вимоги до ефективної державної регіональної політики. Наведено схему формування кластерної моделі національної економіки, який визначає ефективний курс розвитку кластерних моделей національної економіки. Доведено, що формування кластерів шляхом інтегрування регіонів та консолідації галузей дозволить прискорити процес впровадження нових організаційних форм інтеграції та кооперації суб'єктів господарювання, які здійснюють різні види економічної діяльності. Визначено, що активізація інтеграційних процесів буде сприяти зростанню інноваційної активності і нарощування експортного потенціалу, що в кінцевому підсумку дозволить підвищити рівень конкурентоспроможності національної економіки. Сформульовано ряд стратегічних задач, які держава та наукова спільнота повинні вирішити на шляху побудови ефективної кластерної моделі національної економіки.

Ключові слова: кластери, процеси кластеризації, кластерна теорія, кластерні моделі національних економік.

Рис.1, табл.1, літ. 12.

Панкова Л.И., Потапенко Т.П.

\section{ФОРМИРОВАНИЕ КЛАСТЕРНОЙ МОДЕЛИ НАЦИОНАЛЬНОЙ ЭКОНОМИКИ НА ОСНОВ СТИМУЛИРОВАНИЯ РЕГИОНАЛЬНОГО РАЗВИТИЯ}

В статье рассмотрены фундаментальные направления теории региональной экономики и регионального менеджмента, которые стали основой развития кластреной теории. Предоставлено авторское определение кластерной модели развития национальной экономики, обоснованы требования к эффективной государственной региональной политики. Приведена схема формирования кластерной модели национальной экономики, которая определяет эффективный курс развития кластерных моделей национальной экономики. Доказано, что формирование кластеров путем интегрирования регионов и консолидации отраслей позволит ускорить процесс внедрения новых организационных форм интеграции и кооперации субъектов хозяйствования, которые осуществляют различные виды экономической деятельности. Определено, что активизация интеграционных процессов будет способствовать росту инновационной активности и наращивание экспортного потенциала, в конечном итоге позволит повысить уровень конкурентоспособности национальной экономики. 
Сформулирован ряд стратегических задач, которые государство и научное сообщество должны решить на пути построения эффективной кластерной модели национальной экономики.

Ключевые слова: кластеры, процессы кластеризации, кластерная теория, кластерные модели национальных экономик.

\section{Pankova L., Potapenko T.}

\section{FORMATION OF THE CLUSTER MODEL OF NATIONAL ECONOMY ON THE BASIS OF REGIONAL DEVELOPMENT}

The article deals with the fundamental directions of the theory of regional economics and regional management, which became the basis for the development of cluster theory. Author's definition of the cluster model of development of the national economy is provided, requirements for effective state regional policy are substantiated. The scheme of forming a cluster model of the national economy, which determines the effective course of development of cluster models of the national economy, is presented. It is proved that the formation of clusters by integrating regions and consolidating the branches will accelerate the process of introducing new organizational forms of integration and cooperation of business entities that carry out various types of economic activity. It has been determined that activation of integration processes will contribute to the growth of innovation activity and the expansion of export potential, which will ultimately increase the competitiveness of the national economy. A number of strategic tasks, which the state and the scientific community should solve on the way of building an effective cluster model of the national economy, are formulated.

Постановка наукової проблеми. Розвинені країни продовжують боротися 3 низькими темпами економічного зростання. Макроекономічна політика вичерпала свої можливості, а політичні конфлікти перешкоджають економічному розвитку. Конкурентоспроможність національної економіки на світовій арені обумовлена високим рівнем розвитку підприємництва, інновацій та задоволеності потреб суспільного розвитку. Процеси кластеризації здатні активізувати розвиток національної економіки, особливо якщо вони узгоджені зі стратегією, розробленою за участю державних, місцевих органів влади і наукових установ та суспільства в цілому. Тому наукова спільнота продовжує пошук нових теоретичних та методологічних аспектів формування кластерних моделей на рівні територіальних економічних та соціальних систем, які дозволять вирішити завдання на шляху реформування та ефективного розвитку національної економіки.

Аналіз публікацій. Сучасний світовий досвід характеризує кластерний підхід як механізм ефективного розвитку підприємств, який знайшов своє відображення у працях зарубіжних авторів: Т. Андерссона, Т. Бреннера, М. Вебера, Н. Волкової, Я. Дранева, Л. Маркова, А. Маршалла, А. Міграняна, М. Портера, В. Прайс, М. Райсс, Ф. Рейнса, П. Санлі, С. Суіні, В. Трет'яка, Є. Дж. Фезера, І. Ферової, Г. Хасаєва, Т. Цихана, Д. Ялова та інших.

Значний внесок в адаптацію кластерного підходу до вітчизняних умов зробили українські вчені В. Г. Андрійчук, П. П. Борщевський, Н. М. Внукова, М. П. Войнаренко, П. І. Гайдуцький, В. М. Геєць, В. Г. Грановська, О. І. Гуменюк, Л. В. Дейнеко, О. І. 
Драган, Н.Г. Каніщенко, І. Г. Кириленко, Л. В. Левковська, Б. Й. Пасхавер, П. Т. Саблук, Г. А. Семенов, С. І. Соколенко, В. Г. Федоренко, А. В. Череп та інші.

Однак, незважаючи на дискусії, що постійно ведуться зарубіжними i українськими науковцями в цій галузі економічного знання, можна констатувати явну недостатність наукового обгрунтування теоретико-методологіних акспектів формування кластерних моделей національних економік за сучасних принципів ринкового господарювання. Многоаспектність дослідницьких підходів створює поле для наукової дискусії і робить ще більш очевидною необхідність подальшого пошуку нових досліджень в цій сфері.

Мета статті - дослідити теоретико-методологічні аспекти формування кластерних моделей національних економік.

Виклад основного матеріалу й обгрунтування отриманих результатів дослідження. 3 метою дослідження теоретико-методологічних аспектів формування кластерних моделей національних економік доцільно розглянути фундаментальні напрями теорії регіональної економіки та регіонального менеджменту, що стали підгрунтям розвитку кластерної теорії (табл.1).

Особливої уваги заслуговують теорії: теорія полюсів зростання, Концепція економічного районування та територіально-виробничих комплексів (ТВК) та теорія інноваційного розвитку. Так, просторова побудова територіально-виробничих комплексів подібна до побудови промислових кластерів. Однак, суттєвою відмінністю ТВК від промилових кластерів є: відсутність конкуренції; функціонування в умовах планової економіки; жорстке державне регулювання; вертикальний характер зв'язків всередині ТВК.

Теорія полюсів зростання знаходить своє відображення в умовах сьогодення, оскільки полюси конкурентоспроможності існують в сучасній Франції - кластери, які офіційно визнані державою.

Теорія інноваційного розвитку $\epsilon$ актуальною в сучасних умовах розвитку національних економік, оскільки переважна більшість дослідників розділяють думку про те, що інноваційні ефекти кластерів реалізуються завдяки співучасті та балансуванню інтересів провідних інституціональних секторів - науки, бізнесу та влади. Цей механізм, що колись спонтанно склався у Силіконовій долині, пізніше був описаний соціологами як модель потрійної спіралі («Triple Helix Model» Іцковіца-Лейдесдорфа). Він полягає в тому, що області функціонального зчеплення трьох секторів стають універсальною інституціональною матрицею для інноваційного зростання[8].

Наведені загальні теоретико-методичні підходи, дозволяють надати авторське визначення кластерній моделі розвитку національної економіки. Кластерна модель розвитку національної економіки - концептуальний підхід, який передбачає використання кластерів як системоутворюючих елементів сучасної ринкової економіки, що дозволяють реалізувати конкурентні переваги країни в рамках міжнародного економічного простору.

Як показує світовий досвід, така модель покладена в основу стратегії розвитку економічно розвинених країн, іiі практичне використання дозволило забезпечити підвищення ефективності функціонування та конкурентоспроможності їх національних економік. 


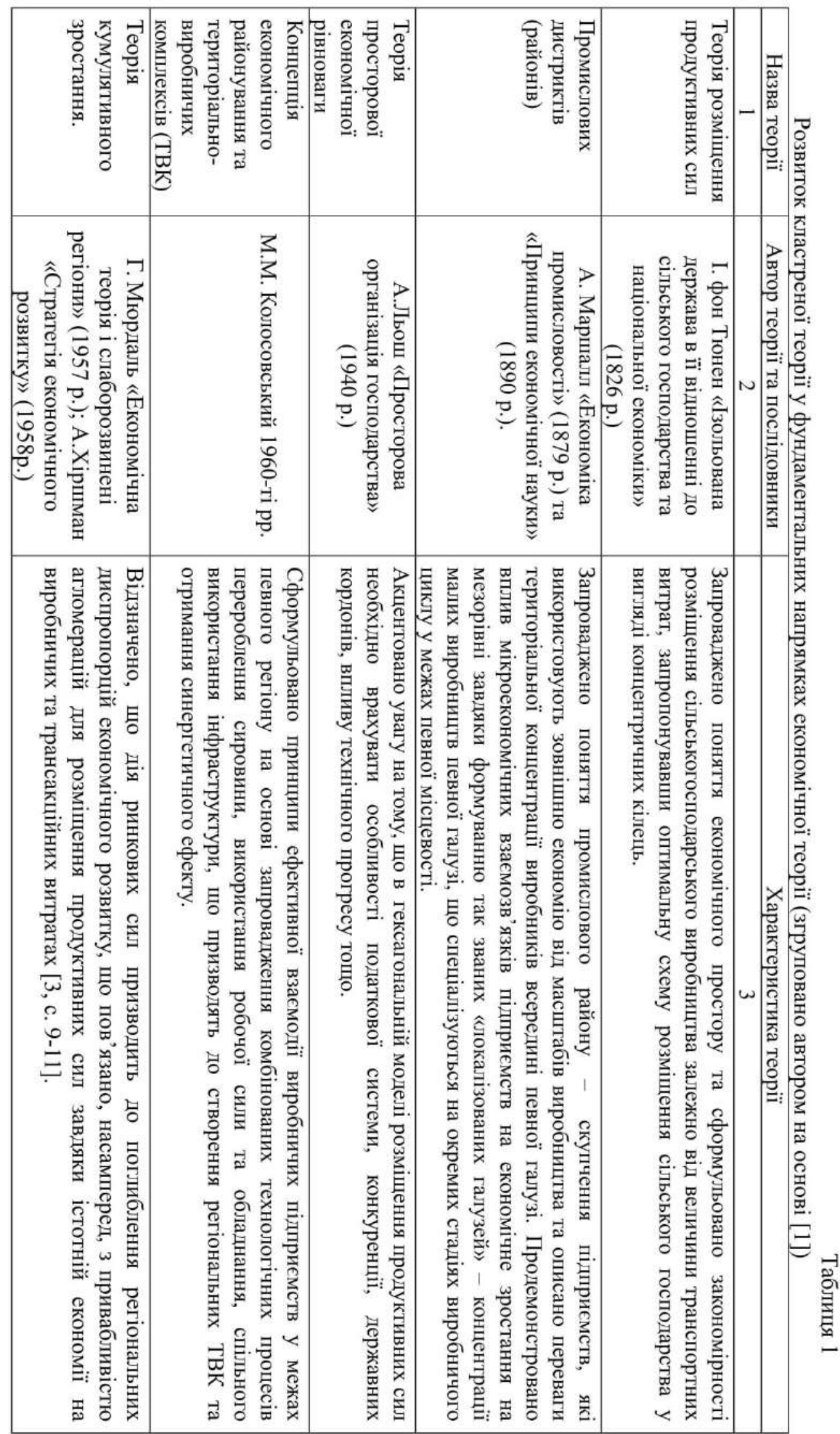




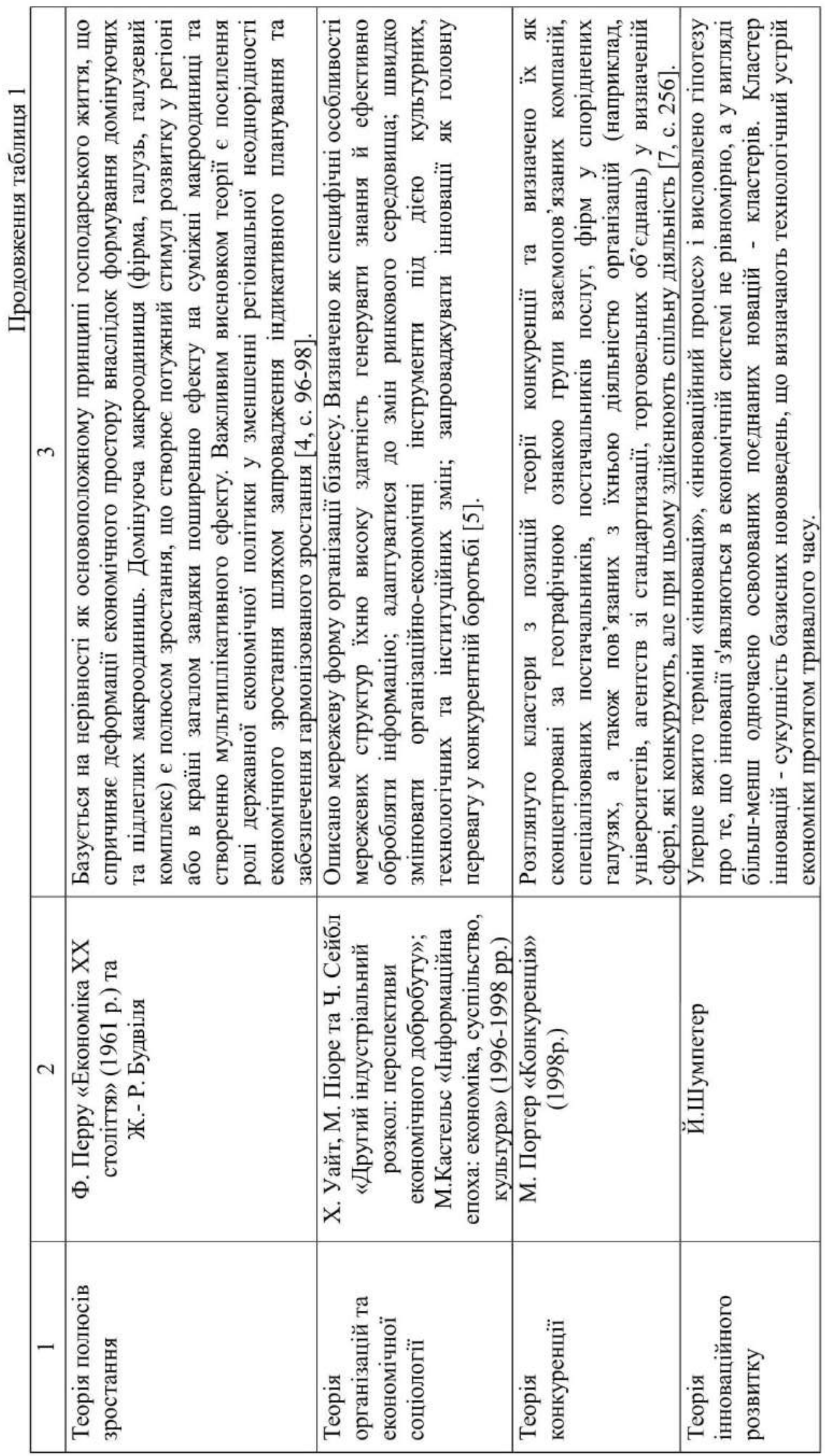


Для реалізації євроінтеграційного курсу та інноваційної політики держави доцільно впровадити в існуючу практику господарювання i управління нових організаційних форм інтеграції та кооперації науки, освіти, виробництва, бізнесу та суспільства. Однією з найбільш ефективних форм такої інтеграції і кооперації є кластери. Цей процес охопив більше половини економік провідних країн світу. В СС налічується понад 2 тис. кластерів, в яких зайнято $38 \%$ його робочої сили. У Китаї сьогодні існує більше 60 особливих зон-кластерів, в яких знаходиться близько 30 тис. фірм 3 чисельністю співробітників 3,5 млн. чол. і обсягом продажів близько 200 млрд. дол. на рік [9].

Однак, система господарювання та управління в Україні обмежує можливості використання кластерної моделі розвитку національної економіки. Кластери, як їх розумів М. Портер, є одним з інструментів ринкової економіки, і найбільш ефективно вони працюють, якщо створюються «знизу-вгору» - з ініціативи приватного бізнесу. При цьому державі відводиться роль регулятора, що визначає правила взаємодії між ним самим, бізнесом і науково-освітніми структурами, а також гаранта збереження і розвитку сприятливих умов для інвестицій, інновацій та розвитку горизонтально-оріснтованих мережевих бізнес-співтовариств і підприємців. Існуючий в Україні механізм господарювання i управління характеризується низьким рівнем конкурентного середовища, високим ступенем концентрації та монополізації виробництва, наявністю жорсткої ієрархічної системи господарського управління, переважанням вертикальних зв'язків над горизонтальними, значним державним сектором [10, с.53].

Дійсно, кластеризація для України є новим процесом, однак для надання йому ефективності необхідно максимально зосередити акцент на наданні популяризації кластерним ініціативам. В іншому випадку такий досвід неминуче призведе до критичних непорозумінь, невірних трактувань, спричинених браком досвіду кластеризації. Збалансоване поєднання малих і середніх підприємств та великих регіоноутворюючих компаній забезпечуватиме міцну основу функціонування кластерів. Зусилля, спрямовані на підтримку кластерів, в яких сконцентровані переважно великі державні компанії та відсутня достатня кількість інноваційно-орієнтованих малих та середніх підприємств, або ж на підприємства галузі, які територіально розпорошені, не матимуть очікуваного впливу [10, с.53].

На думку автора, спрощена схема формування кластерної моделі національної економіки повинна мати вигляд (рис.1). Таким чином, формування ефективної кластерної моделі розвитку національної економіки можливе за умови:

зміни інституційного середовища, включаючи послідовне реформування відносин власності;

формування значного сектора малого i середнього підприємництва та, як наслідок, сприятливого конкурентного середовища;

ефективне та системне втручання держави на рівні регуляторної політики (підтримки малого та середнього бізнесу; кластерної політики).

Це передбачає інвестиційно-структурну перебудову економіки 3 поступовим заміщенням традиційних галузей на більш високотехнологічні та інноваційні, чітке розмежування функцій державного регулювання та господарського управління. Для цього потрібна підготовка і прийняття відповідних управлінських рішень високого рівня, які стануть основою необхідної нормативно-правової бази, і здійснення організаційнометодичного та планово-прогностичного забезпечення державних органів щодо формування та розвитку кластерних утворень, що створюватимуться як в рамках державних та підприємницьких ініціатив інноваційного розвитку. 


\section{АКТИВІЗАЦІЯ СОЦАЛЬНОГО ТА ЕКОНОМІЧНОГО РОЗВИТКУ НАЦІОНАЛЬНОЇ ЕКОНОМІКИ НА ЗАСАДАХ СТМУЛЮВАННЯ РЕГІОНІВ}

\begin{tabular}{l}
\hline Розвиток малого та \\
середнього бізнесу
\end{tabular}
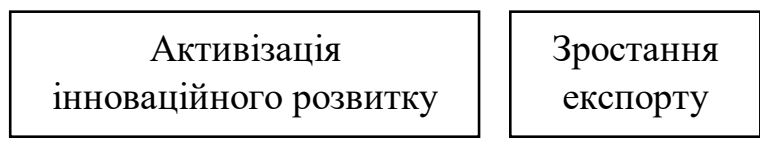

Збільшення зайнятості

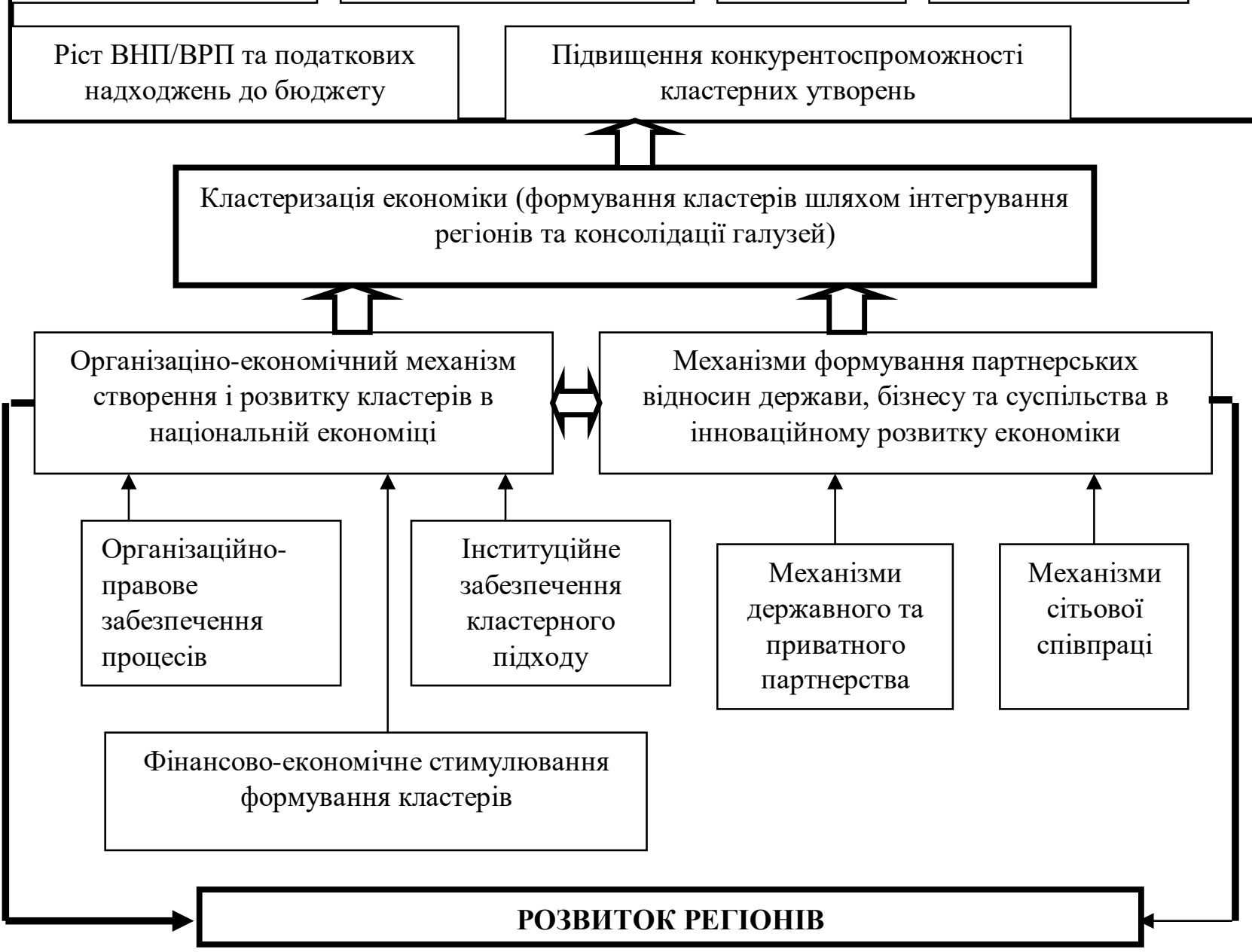

Рисунок 1 - Схема формування кластерної моделі національної економіки

На думку автора, ці заходи мають визначити ефективний курс розвитку кластерних моделей національної економіки. Це дозволить прискорити процес впровадження нових організаційних форм інтеграції та кооперації суб'єктів господарювання, які здійснюють різні види економічної діяльності, і буде сприяти зростанню інноваційної активності і нарощування експортного потенціалу, що в кінцевому підсумку дозволить підвищити рівень конкурентоспроможності національної економіки.

Слід зауважити, що державна політика в області підтримки процесів кластеризації повинна визначатися національними особливостями розвитку економіки та суспільними потребами. Така підтримка може здійснюватися за допомогою:

Концепції державної кластерної політики (за галузевим принципом); стратегії формування кластреної моделі та виділеним бюджетом; 
політики, сфокусованої на деяких аспектах розвитку кластерів (сітьової взаємодії між суб'єктами розвитку процесів кластеризації);

реалізації стратегічних напрямків економічного розвитку, що впливають на розвиток кластерних утворень;

цільових принципів кластерної політики та узагальнених підходів до кластероутворення.

Нині очевидно, що за останнє десятиріччя почав стрімко зростати інтерес до кластерів у країнах Свропи, оскільки в умовах ринкового господарства вони стали справжньою рушійною силою виробництва в компаніях, які є їх учасниками. Україні, як одній з великих європейських держав, потрібно у програмах розвитку враховувати той факт, що всі країни Європи вже мають і здійснюють свої національні програми кластеризації [11, с.5].

Всі країни - члени Європейського Союзу у рамках рішення Європейського Саміту, що відбувся у Лісабоні у 2000 році, орієнтовані, спираючись на формування та розвиток кластерів, на забезпечення створення в Європі найбільш конкурентоспроможної та динамічної економіки знань, здатної наздогнати і навіть перегнати США та Японію за показниками постійного економічного зростання. Протягом 1990-х років спостерігалося постійне збільшення кількості промислових кластерів у різних куточках планети. Від Шотландії до Бангалора (науковий центр в Індіi), від Сінгапуру до Ізраїлю формула успіху проявляється в інтенсивному розвитку інноваційних промислових кластерів. Про значущість розвитку промислових кластерів свідчить той факт, що на форумі Європалат у липні 2006 році був прийнятий Маніфест про розвиток кластерів у країнах Свропи. У цьому документі, до речі, говориться про позитивний досвід розвитку кластерів у деяких регіонах України, у тому числі на Поділлі, Поліссі, Прикарпатті та в Севастополі. У своєму Зверненні до Ради від 13 вересня 2006 року Європейська комісія наголосила, що бути частиною кластера важлива конкурентна перевага бізнесу. Кластери допомагають заповнити прогалини між бізнесом, дослідженням та ресурсами і, таким чином, швидше видають знання на ринок. Потрібно зазначити, що успішні кластери пропагують інтенсивну конкуренцію одночасно із співпрацею. Вони збільшують продуктивність, залучають інвестиції, пропагують дослідження, посилюють промислову базу, розробляють спеціальні продукти і послуги, стають основою для розвитку навичок. Нове покоління програм Європейської регіональної політики на 2007 - 2013 роки пропонує використати підхід, що базується на регіональних інноваційних кластерах, не тільки в розвинутих міських центрах, але і в бідніших сільських регіонах [11, с.7].

Важливе значення у реалізації державної підтримки розвитку кластерів за кордоном має формування спеціальної інфраструктури. Як правило, реалізація кластерних стратегій передбачає наявність грантоутворюючих фондів (інститутів, агентств), які підтримують кластерні ініціативи: наприклад [12]:

Національне агентство планування DATAR (Франція),

Iнформаційна система пошуку та класифікації кластерів CASSIS (Люксембург),

Національна рада 3 конкурентоспроможності (США),

програма кооперації LINK (Великобританія) [12].

Формування ефективної кластерної моделі процес складний та унікальний він залежить від системної та цілеспрямованої державної кластерної політики. Цей процес доцільно охарактеризувати як перехід: 
від набуття певних специфічних рис національними економіками до їх функціональної означеності в рамках формування як соціальних та економічних відносин в країні, так, і економіко-політичних відносин на міжнародній арені;

системного стимулювання регіонального розвитку за цільовими моделями (регіони - точки зростання; кумулятивного зростання та ін.).

Враховуючи сучасну масштабність глобалізації та соціально-економічних процесів, що виявляється у кластеризації світової економіки, відбувається взаємна інтеграція соціальних, політичних, економічних, регіональних, галузевих і культурних ознак країн, які обумовлюють синергетичний прояв їх впливу. Таким чином, участь у міжнародних процесах обумовлює неможливість уникнення країною загальносвітових тенденцій та вимагає певних стратегічних урядових дій щодо активізації та побудови ефективної кластерної моделі економіки з цільовим вектором - стимулювання розвитку регіонів.

Досвід свідчить, що найчастіше регіональний поділ формується історично протягом тривалого часу, однак він не завжди враховує усі економічні, технологічні, географічні особливості. Сьогодні існують нові теоретичні та практичні знання, управлінські механізми, за допомогою яких різні галузі спрямовують та поєднують технічний та технологічний, економічний та соціальний прогрес. Одним з напрямів такого прогресу слід визнати регіональну та галузеву кластеризацію. Такий рух формує значні вигоди та перспективи розвитку - регіонів, підприємств, галузей, національних економік. На практиці можливе не лише економічне чи регіональне застосування відповідних технологій. Будь-які об'єкти чи явища, що мають ознаки однотипності, співрозмірності, типовості можуть бути згруповані в кластерні об'єднання та формувати низку синергетичних ефектів в процесі активної, інноваційної взаємодії [10, с.59].

Так, державна політика та наукова спільнота повинні вирішити ряд стратегічних задач на шляху побудови кластерної моделі національної економіки. Серед яких:

1. Визначити методичний інструментарій щодо точного визначення меж кластеру. В умовах формування міжнародного кластерного утворення специфіка економічної структури країн, що входять до кластеру, свідчитиме про спеціалізацію та відповідну політико-економічну роль країни в межах світової спільноти.

2. Забезпечити процес збалансованості складу економічних секторів в кластерній моделі національної економіки з урахуванням їх взаємозалежності.

Потреба у переході від визнання домінуючої ролі того чи іншого сектору економіки до обгрунтування економічної структури країни (кластеру) вимагає 3'ясування ролі кожного сектору економіки в кластерній моделі національної економіки. Необгрунтоване зростання будь-якого з секторів економіки свідчить про дисбаланс, який може виникати внаслідок неефективної державної політики, що не враховує соціальні та економічні потреби суспільства.

Висновки та перспективи подальшого дослідження.Таким чином, ідея формування кластерних моделей національних економік не нова. Але за сучасних умов розвитку економіки, що супроводжується пошуком шляхів виходу з кризи, натиском глобальної конкуренції використання кластерної моделі організації бізнесу є тим інструментом модернізації економіки, що дозволить активізувати процеси інноваційної діяльності та відповідати вимогам національного й регіонального розвитку у відповідності до європейських стандартів.

На сьогодні існує ряд невирішених проблем, що заважають побудові ефективної кластерної моделі національної економіки, а саме: не визначено специфіку процесів кластеризації в українській економіці, що стосується інституційних та соціальних 
особливостей; не виявлено найбільш перспективні сфери кластеризації в реаліях української економіки; не окреслено проблеми балансу інтересів учасників кластеризації; не визначено методологію соціальних інновацій та процесів кластеризації, тощо. Все це окреслює коло подальших наукових досліджень.

\section{СПИСОК ВИКОРИСТАНИХ ДЖЕРЕЛ}

1. Кластерні об'єднання: міжнародний досвід та українські реалії / М. Войнаренко, А. Береза // Економіст. - 2013. - № 10. - С. 27-30

2. Пилипенко И. В. Принципиальные различия в концепции промышленных кластеров и территориально-производственных комплексов. // Вестник Московского Университета. Серия 5. География. - 2004, №5. - С. 3-9.

3. Мельников Р. М. Проблемы теории и практики государственного регулирования экономического развития регионов: Монография. - М.: Изд-во РАГС, 2006. - 209 с.

4. Глух Н. А. Институционально-социологическая традиция во Франции. Ф. Перру История экономических учений: (современный этап). Под ред. А. Г. Худокормова. М.: Инфра-М. 1998. - 733 с.

5. Кастельс М. Информационная эпоха: экономика, общество, культура. http://www.gumer.info/bibliotek_Buks/Polit/kastel/03.php

6. Корчагина, Н. А. Кластерная политика - технология повышения эффективности управления компаниями [Текст] : монография / Н. А. Корчагина. -Астрахань : Издательский дом «Астраханский университет», 2009. - 117 с.

7. Портер Майкл Конкуренция: Пер. с англ. - М.: Издательский дом "Вильямс", 2005. $-608 \mathrm{c}$.

8. Smorodinskaja N. (2013) "Regional Innovation Clusters: Global Guidelines and Russian Realities", at:http://regconf.hse.ru/uploads/ede481990d3d34e296401e66fdf53518aa7e6ce6.pdf

[Online], available

9. Synopsis of Policy Options for Creating a Supportive Environment for Innovative Development. ECE/CECI/2008/3, Geneva, 9 September 2008

10. Гулак Д.В. Розвиток електроенергетичного ринку України на засадах регіональної кластеризації: монографія. Черкаси: видавець Пономаренко Р.В., 2018. - 286 с.

11. Оскольський В. Кластеризація - вагомий фактор підвищення конкурентоспроможності економіки України. Економіка України. 2014. № 11. С. 4-16.

12. Solvell O., Lindqvist G., Ketels Ch. The Cluster Initiative Greenbook. The Competitiveness Institute / VINNOVA, Gothenburg, 2003. 